\title{
Prevalence of rotavirus infection and its association with socio-demographic characteristics among under-five children admitted with acute diarrhoea in a tertiary care hospital of Bangladesh
}

\author{
Habib FB ${ }^{a}$, Rahman MM $^{b}$, Choudhury R $^{\mathrm{c}}$, Paul TK ${ }^{\mathrm{d}}$, Haque MM ${ }^{\mathrm{e}}$
}

\begin{abstract}
Background: Rotavirus has been recognized as the most common cause of acute watery diarrhoea among under-five children worldwide. It is considered as a major cause of childhood morbidity and mortality particularly in developing countries like Bangladesh. Considering the high morbidity and significant mortality, this study was designed to evaluate the prevalence of rotaviral diarrhoea among children less than five years in Sylhet region of Bangladesh.

Methods: This cross-sectional study was conducted in the Department of Microbiology, Sylhet MAG Osmani Medical College from 1st January to 31st December, 2018. Total 184 under-five children admitted in paediatrics department of the same institute with acute watery diarrhoea were enrolled in this study by convenient sampling. Stool samples were obtained and assayed for rotavirus antigen by sandwich type enzyme linked immunosorbent assay (ELISA).

Results: Rotaviral antigen was found positive in 86 cases and disease prevalence was $46.74 \%$. The rotavirus inf-ection was found highest in age group of 7 to 12 months (50.56\%) and in male (59.30\%) children. Prevalence of infection was associated with age $(\mathrm{p}=0.004)$, socio-economic condition $(\mathrm{p}=0.001)$ and exclusive breastfeeding of children $(\mathrm{p}=0.01)$.
\end{abstract}

Conclusion: Rotavirus was a significant cause of acute watery diarrhoea and mainly affected children below 12 months age.

Key words: enzyme linked immunosorbent assay, prevalence, rota virus, watery diarrhea.

(BIRDEM Med J 2021; 11(3): 186-190)

\section{Author information}

a. Farjana Binte Habib, Lecturer, Department of Microbiology, Dhaka Medical College, Dhaka, Bangladesh.

b. Mohammed Mirazur Rahman, Resident (MD Phase B), Pulmonology, Bangabandhu Sheikh Mujib Medical University (BSMMU), Shahabag, Dhaka, Bangladesh.

c. Rafaat Choudhury, Assistant Professor (Microbiology), National Institute of Preventive and Social Medicine (NIPSOM), Mohakhali, Dhaka, Bangladesh.

d. Tarun Kanti Paul, Lecturer, Department of Microbiology, Sylhet MAG Osmani Medical College, Sylhet, Bangladesh.

e. Md. Moynul Haque, Professor and Head of the Department of Microbiology, Sylhet MAG Osmani Medical College, Sylhet, Bangladesh.

Address of correspondence: Farjana Binte Habib, Lecturer, Department of Microbiology, Dhaka Medical College, Dhaka, Bangladesh. Email: farjanahabib33@gmail.com

Received: December 26, 2020

Revision received: March 30, 2021

Accepted: June 30, 2021

\section{INTRODUCTION}

Rotavirus is one of the most important public health concern and one of the major causes of acute watery diarrhoea in children below five years. ${ }^{1}$ This virus was first described by electron microscopic examination of duodenal biopsies from children with acute gastroenteritis. ${ }^{2}$ Rotavirus is classified into seven groups, A to G. Group A is responsible for more than $90 \%$ of rotavirus gastroenteritis in infants and young children. ${ }^{1,3}$ Rotavirus is transmitted through the faecooral route having low infective dose. ${ }^{4}$

Rotaviral diarrhoea is contributing a significant proportion of morbidity and mortality in under-five children. It causes approximately 121,000 deaths in developing countries of Africa and South Asia and approximately 215,000 deaths per year in children less than 5 years of age worldwide. ${ }^{5}$ 
In Bangladesh, rotavirus is the major cause of underfive diarrhoea and diarrhoeal deaths. ${ }^{6}$ According to world health organization (WHO), rotaviral diarrhoea causes 1000-2700 deaths each year in children $<5$ years of age in Bangladesh. ${ }^{7}$

Several risk factors are responsible for rotaviral infection in children like low birth weight, male gender, 6-24 months age group (due to more exposure to contaminated materials in this age group), children attending daycare, poor food hygiene, playing with toys, bottle-feeding, low literacy status of mother. 8,9

Clinical presentation of rotaviral diarrhoea resembles the same as in diarrhoea due to other etiology. It has no specific anti-viral treatment. Good hygiene reduces the transmission of virus. But even in the most hygienic societies, virtually all children experience rotaviral diarrhoea as a result of high infectivity of the virus. Considering the high morbidity and significant mortality, this study was designed to know the prevalence of rotaviral diarrhoea among children less than 5 years in Sylhet region.

\section{METHODS}

This cross-sectional study was carried out in the department of Microbiology, Sylhet MAG Osmani Medical College in collaboration with the department of Paediatrics of Sylhet MAG Osmani Medical College Hospital, Sylhet from 1st January 2018 to 31st December 2018. All admitted children under 5 years of age with acute watery diarrhoea were included in this study. Children suffering from chronic diarrhoea (diarrhoea for $\geq 14$ days) and bloody diarrhea were excluded. After explaining the purpose of the study, informed written consent was taken from patient's legal guardians. Data collection was done by pre-designed data collection sheet. Prior to the beginning of this study, approval of the research protocol was obtained from the Ethical Review Committee of Sylhet MAG Osmani Medical College, Sylhet.

Socio-economic conditions were ascertained by the income of the head of the family. Study population were classified into lower and middle socio-economic income group. Those who had monthly income of $<5000$ taka and 5000 to 15000 taka were stratified in lower and middle income group respectively.
The patients residing within Sylhet city were classified as urban poeple and those residing outside Sylhet city were classified as rural poeple.

\section{Specimen collection}

Fresh stool samples were collected from the admitted patients in properly labeled clean, dry, wide mouthed, leak-proof plastic containers. Stool samples were carried to the laboratory within 1 to 2 hours of collection.

\section{Laboratory procedure}

Macroscopic examination was done for colour, consistency, presence of mucus in stool samples.

Rotaviral antigen detection by enzyme linked immunosorbant assay (ELISA)

Monoclonal antibodies against the product of the sixth viral protein (VP6) used in a sandwich type method. The assay was carried out according to the manufacturer's instructions.

\section{Statistical methods}

For data analysis, $\chi^{2}$ (Chi square) test was done and $\mathrm{p}<0.05$ was considered significant.

\section{RESULTS}

Distribution of study subjects according to stool antigen test by ELISA.

In our study, rotaviral antigen was found positive in 86 and negative in 98 patients. In our study, prevalence of rotavirus diarrhoea was found $46.74 \%$.

Prevalence and distribution of ELISA positive rotavirus diarrhoea.

It was revealed from our study that, prevalence of rotavirus induced acute watery diarrhoea (ELISA positive) was highest among 7-12 months age group children $(50.56 \%)$ followed by $13-24$ months age group children (48.28\%). This prevalence was also higher among male children $(59.30 \%)$ and children from low socio-economic status $(64.00 \%)$ compared to female and middle socio-economic status (26.19\%) respectively. This prevalence was also higher among children of rural residence (48.75\%) than the children of urban counterparts. Our study found that, prevalence of rotavirus diarrhoea was higher among children who were not exclusively breastfed $(83.87 \%$, $p<0.01)$ and this association was statistically significant (Table I). 
Table I Prevalence of rotavirus diarrhoea among under-5 years children according to their socio-demographic status $(\mathrm{N}=184)$

\begin{tabular}{|c|c|c|c|c|c|}
\hline \multirow[t]{2}{*}{ Variables } & \multicolumn{2}{|c|}{ ELISA (+ve) } & \multicolumn{2}{|c|}{ ELISA (-ve) } & \multirow[t]{2}{*}{$P$ value } \\
\hline & $\mathrm{n}$ & $(\%)$ & $\mathrm{N}$ & $(\%)$ & \\
\hline \multicolumn{6}{|l|}{$\overline{\text { Age (months) }}$} \\
\hline $0-6$ & 2 & 11.11 & 16 & 88.89 & \multirow[t]{4}{*}{$0.004 *$} \\
\hline $7-12$ & 50 & 50.56 & 40 & 49.44 & \\
\hline $13-24$ & 28 & 48.28 & 30 & 51.72 & \\
\hline $25-59$ & 6 & 33.33 & 12 & 66.67 & \\
\hline \multicolumn{6}{|l|}{ Gender } \\
\hline Male & 51 & 59.30 & 71 & 72.45 & \multirow[t]{2}{*}{0.060} \\
\hline Female & 35 & 40.70 & 27 & 27.55 & \\
\hline \multicolumn{6}{|l|}{ Socioeconomic status } \\
\hline Middle & 22 & 26.19 & 62 & 73.81 & \multirow[t]{2}{*}{$0.001 *$} \\
\hline Lower & 64 & 64.00 & 36 & 36.00 & \\
\hline \multicolumn{6}{|l|}{ Residence } \\
\hline Urban & 8 & 33.33 & 16 & 66.67 & \multirow[t]{2}{*}{0.158} \\
\hline Rural & 78 & 48.75 & 82 & 51.25 & \\
\hline \multicolumn{6}{|l|}{ Breast feeding } \\
\hline Exclusive brest feeding (EBF) & 32 & 26.23 & 90 & 73.77 & \multirow[t]{2}{*}{$0.01 *$} \\
\hline NoEBF & 52 & 83.87 & 10 & 16.13 & \\
\hline
\end{tabular}

$* \mathrm{P}$ value $<0.05$ statistically significant

\section{DISCUSSION}

In our study, prevalence of rotavirus diarrhoea was $46 \%$ and this result is similar to different studies done in Bangladesh and other countries. Ahmed et al. conducted a study in the Institute of Child and Mother Health, Matuail, Dhaka, Bangladesh in 2009 and found the prevalence of rotaviral infection to be $41.8 \% .{ }^{10} \mathrm{~A}$ study conducted by Afrad and colleagues in Matlab, Bangladesh from 2006 to 2012 revealed that prevalence of rotaviral diarrhoea was $20.3 \%$ among under-5 children. ${ }^{11}$ In Sri Lanka, Singh et al. in 2014 did a hospitalbased study and found the prevalence of rotaviral diarrhoea to be $44 \% .{ }^{12}$ A study conducted in Pakistan in 2014 found the prevalence of $30.5 \% .{ }^{13}$ In 2017, Dhital et al. conducted a study in Nepal and found 22.9\% patient with positive rotaviral stool antigen. ${ }^{14}$ Prevalence of rotaviral diarrhoea was $26.4 \%$ among under- 5 children in a hospital based cross-sectional study conducted in Tanzania. ${ }^{15}$ A study conducted in Tripura, India showed that prevalence of rotaviral diarrhoea was $36 \%$ in children below 5 years of age. ${ }^{16}$
In the present study, highest prevalence of rotaviral diarrhoea was found in children of 7-12 months of age group. This is in agreement with the results of a study done in Nigeria where most of the infected children (42\%) were between 7 to 12 months of age group. ${ }^{10}$ It appeared that infants below 6 months of age are initially protected to some extent against rotavirus diarrhoea due to presence of maternal antibodies. After 6 months when maternal antibody decreases, rate of infection increases. ${ }^{16}$ In this age group ( $7-12$ months), children start crawling and develop tendency to put almost everything into mouth which can increase the chance of infection. ${ }^{11}$ Another reason can be that the weaning is started at this age. So, there is chance of contamination of food during preparation if hand washing and food hygiene is not maintained properly. Frequency of rotaviral infection was less in higher age group due to acquisition of antibody by natural infection. ${ }^{10}$ 
In this study, highest prevalence of rotaviral diarrhoea was found among male gender. This result is in agreement with previous Bangladeshi studies, where it was reported that around $58 \%{ }^{17}$ and $54 \%{ }^{18}$ children were male. Similar result was found from an Indian study done by Agarwal and co-workers where 62.7\% male children were affected ${ }^{19}$ and an Ethiopian study done by Sisey et al. who found that rotaviral affected male was $59.6 \%$. $^{20}$ This male predominance is not clearly understood. It can be explained by social reason that the tendency of parents to prioritize their male children than female in seeking any kind of health care. This finding can also be explained by more resistance to infection in females due to XX chromosome. ${ }^{21}$ However, this difference was not statistically significant.

This study revealed that the rotaviral diarrhoea was higher among children who belong to lower socioeconomic status than the children from middle socioeconomic status. This finding is in resemblance with the finding of an Indian studies done in Amritsar. ${ }^{21}$ This can be explained by unhygienic behaviour, not having or using sanitary latrine and less ability to avail standard health care facility. As rotaviral infection is highly communicable, overcrowding living condition can also explain this finding. As the treatment in private hospital is expensive, the poor usually come to the government hospital. It might be one of the reasons of more availability of poor patients in our study. So, this picture may not represent the actual situation.

Present study also found that, prevalence of rotavirus diarrhoea was higher among children who were from rural area compared to their urban counterparts. This finding is in harmony with a previous finding of a study done in Ethiopia where $96.5 \%$ positive cases were from rural area. ${ }^{20}$ It can be explained by lack of health education, improper sanitation or lower availability of health care facility in rural areas comparing to urban areas.

Present study found that, prevalence of rotavirus diarrhoea was higher among children who were not exclusively breastfed and this association was found statistically significant. This finding is found similar with a Bangladeshi study done by Ferdous et al. ${ }^{22}$ and another study done in Iraq by Azeez and Alsakee ${ }^{23}$ found a higher incidence of rotavirus diarrhoea in infants those were not exclusively breastfed. This finding can be explained by the protective immunological effects of breastmilk in infants and young children. $\operatorname{IgA}$ and $\operatorname{IgG}$ from colostrum and breast milk protects children from rotavirus infection and also reduces the severity of rotavirus diarrhoea. Lactadherin and oligosaccharide of breast milk prevent rotavirus from binding with the receptor of small intestine. ${ }^{24,25}$ Previous studies conducted among under-5 years old children in other countries like India and Nepal also reported that incidence of rotaviral diarrhoea increases after 6 months of age. They suggested that exclusive breast feeding is the main reason of lower incidence of rotaviral diarrhoea during first 6 months of life. ${ }^{14,21}$

\section{Conclusion}

In our study, prevalence of rotavirus diarrhoea was $47 \%$ and was found significantly higher in children of 7-12 months old with males more susceptible to rotavirus infection than females. It was also found higher in children from lower socio-economic condition, rural area, who were not exclusively breastfed. The strategies for rotavirus control include identifying the target population for rotavirus, educating parents and prompt diagnosis. However, the significant higher prevalence in children with lower age and low provision of breast feeding emphasizes the need to pay attention as an important factor of rotavirus diarrhoea. It is particularly important in Bangladesh, where diarrhoea is still contributing a significant proportion of mortality and morbidity in under-five children.

\section{Limitations}

1. The study was conducted in a single center which may not represent the overall disease burden in different other hospitals and geographical locations of the country.

2. Sample size was small.

3. We could not perform genotyping.

\section{Recommendations}

Further studies with large sample size involving multicenter should be carried out to determine the actual disease burden.

Authors' contribution: MMH designed the concept and involved in critical review of the manuscript. FBH and TKP were involved in sample collection and manuscript writing. FBR performed test and analyzed data. MMR was involved in data analysis. RC was involved in review of manuscript.

Conflicts of interest: Nothing to declare.

Funding: Self-funding. 


\section{REFERENCES}

1. Pang X, Hodinka RL. Gastroenteritis Viruses. In: Jorgensen JH, Pfaller MA eds. Manual of clinical microbiology; 11th ed. Washington DC: ASM press 2015; p. 1617-32.

2. Bishop RF, Davidson GP, Holmes IH, Ruck BJ. Virus particles in epithelial cells of duodenal mucosa from children with acute non-bacterial gastroenteritis. Lancet 1973; 302(7841):1281-3.

3. Estes MK, Greenberg HB. Rotaviruses. In: Knipe DM, Howley PM eds. Fields Virology; $6^{\text {th }}$ ed. Philadelphia: Lippincott Williams \& Wilkins 2013; p. 1347- 1401.

4. Miller S. Reoviruses, Rotaviruses, and Caliciviruses. In: Carroll KC, Morse SA, Meitzner TA, Miller S eds. Jawetz, Melnick \& Adelberg's Medical Microbiology; $27^{\text {th }}$ ed. New York: McGraw-Hill 2016; p. 532-6.

5. Tate JE, Burton AH, Boschi PC, Parashar UD. Global, regional and national estimates of rotavirus mortality in children $<5$ years of age, 2000-2013. Clin Infect Dis 2016; 62(2):96-105.

6. UNICEF. Committing to Child Survival: A Promise Renewed. Progress Report 2015. New York, 2015: 8-25.

7. World Health Organozation. Rotavirus deaths by country 2000-2013. web page at www.who.int/immunization/ monitoring surveillance/rotavirus [accessed on 12/08/ 2018].

8. Bernstein DI. Rotavirus overview. Pediatr Infect Dis J 2009; 28(3):50-3.

9. Junaid SA, Umeh C, Olabode AO, Banda JM. Incidence of rotavirus infection in children with gastroenteritis attending Jos University Teaching Hospital, Nigeria. Virol J 2011; 8(233):1-8.

10. Ahmed S, Kabir ARM, Rahman A, Hussain M, Khatoon S, Hannan A. Severity of Rotavirus diarrhea in children: One Year Experience in a Children Hospital in Bangladesh. Iran J Pediatr 2009; 19(2):108-16.

11. Afrad MH, Hassan Z, Farjana S, Moni S, Barua S, Das SK, et al. Changing profile of rotavirus genotypes in Bangladesh, 2006-2012. BMC Infect dis 2013; 13(320):1-7.

12. Singh G, Singh GD, Arora S, Singh G, Agarwal A. A descriptive hospital based study of rotavirus diarrhoea in children aged 6 months to 3 years. Sri Lanka J Child Health 2014; 43(4): 219-23.

13. Kazi AM, Warraich GJ, Qureshi S, Qureshi H, Khan MMA, Zaidi AKM, et al. Sentinel Hospital-Based Surveillance for Assessment of Burden of Rotavirus Gastroenteritis in Children in Pakistan. PLoS One 2014; 9(10):1-7.

14. Dhital S, Sherchand JB, Pokhrel BM, Parajuli K, Shah N, Mishra SK, et al. Molecular epidemiology of Rotavirus causing diarrhea among children less than five years of age visiting national level children hospitals, Nepal. BMC Pediatr 2017; 17(101):1-7.

15. Mchaile DN, Philemon RN, Kabika S, Albogast E, Morijo KJ, Kifaro E, et al. Prevalence and genotypes of Rotavirus among children under 5 years presenting with diarrhoea in Moshi, Tanzania: a hospital based cross sectional study. BMC Res Notes 2017; 10(542):1-6.

16. Majumder N, Barbhuiya NI, Majumder T, Datta SS. Prevelence of Rotaviral infection among children admitted with acute diarrhea in a tertiary care hospital of Tripura. Int J Sci Res 2018; 7(3): 105-7.

17. Roy S, Shamsuzzaman SM, Mamun KZ. Rapid detection of Rotavirus antigen in stool sample of acute diarrheic children. Ban J Med Microbiol 2012; 6(1):11-3.

18. Verkerke H, Sobuz S, Ma JZ, Petri SE, Reichman D, Qadri F, et al. Malnutrition Is Associated with Protection from Rotavirus Diarrhea: Evidence from a Longitudinal Birth Cohort Study in Bangladesh. J Clin Microbiol 2016; 54(10):2568-74.

19. Agarwal JK, Garg SP, Dayachand, Agarwal D. Comparative Analysis of Enzyme-Linked Immunosorbent Assay and Rapid Card Test for Diagnosis of Rotavirus Antigen in Acute Diarrhea Below Five Years Children. Int J Curr Microbiol Applied Sci 2016; 5(7):289-94.

20. Sisay MM, Gedefa SM, Zeleke AJ, Solleny GA. Risk Factors of Rotavirus Outbreak Among Children in Kurmuk District, Benishangul Gumuz Regional State, Ethiopia. JOJ Case Stud 2018; 8(1):1-6.

21. Dhiman S, Devi B, Singh K, Devi P. Comparison of Enzyme-Linked Immunosorbent Assay and Immunochromatography for Rotavirus Detection in Children Below Five Years with Acute Gastroenteritis. J Clin Diagn Res 2015; 9(9):6-9.

22. Ferdous F, Das SK, Ahmed S, Farzana FD, Latham JR, Chisti MJ, et al. Severity of Diarrhea and Malnutrition among Under Five-Year-Old Children in Rural Bangladesh. Am J Trop Med Hyg 2013; 89(2):223-8.

23. Azeez SS, Alsakee HM. Cryptosporidium spp. and rotavirus gastroenteritis and change of incidence after rotavirus vaccination among children in Raparin Pediatrics Hospital, Erbil, Iraq. Med J Indones 2017; 26(3):190-7.

24. Morrow AL, Ruiz-Palacios GM, Jiang X, Newburg DS. Human-milk glycans that inhibit pathogen binding protect breast-feeding infants against infectious diarrhea. J Nutr 2005; 135(5): 1304-7.

25. Newburg DS, Peterson JA, Ruiz-Palacios GM, Matson DO, Morrow AL, Shults J, et al. Role of human-milk lacadherin in protection against symptomatic rotavirus infection. Lancet 1998; 351(9110):1160-4. 